\title{
Urea distribution and uptake in the Atlantic Ocean between $50^{\circ} \mathrm{N}$ and $50^{\circ} \mathrm{S}$
}

\author{
Stuart C. Painter ${ }^{1, *}$, Richard Sanders ${ }^{1}$, Howard N. Waldron ${ }^{2}$, Michael I. Lucas ${ }^{1,3}$, \\ Sinhue Torres-Valdes ${ }^{1}$ \\ ${ }^{1}$ Ocean Biogeochemistry and Ecosystems, National Oceanography Centre, Southampton, European Way, Southampton, \\ SO14 3ZH, UK \\ ${ }^{2}$ Department of Oceanography, University of Cape Town, Private Bag, Rondebosch 7701, Cape Town, South Africa \\ ${ }^{3}$ Present address: Department of Zoology, University of Cape Town, Private Bag, Rondebosch 7701, Cape Town, South Africa
}

\begin{abstract}
We investigate the distribution of urea and its uptake by phytoplankton during 3 meridional transects of the Atlantic Ocean between $50^{\circ} \mathrm{N}$ and $50^{\circ} \mathrm{S}$. Significant relationships were identified between urea uptake and Prochlorococcus abundance $(p<0.01)$ in the northern subtropical Atlantic, where Prochlorococcus appears likely to dominate urea uptake, and between urea concentration and the $<200 \mu \mathrm{m}$ microplankton biomass fraction $(\mathrm{p}<0.005)$ in the South Atlantic, which may be associated with the production of urea. These results suggest that the distribution of urea in the subtropical ocean may be controlled by regional imbalances between urea consumption and urea production. In parallel with these simple relationships significant spring-autumn seasonal changes in the distribution of urea were identified in southern subtropical and tropical latitudes. Urea was twice as abundant during local spring than during local autumn in the subtropical South Atlantic but 2.5 times more abundant in equatorial waters during the boreal autumn period. Euphotic zone integrated urea uptake rates also varied seasonally, being considerably higher in the North Atlantic temperate and subtropical latitudes during the boreal spring whilst in the subtropical South Atlantic urea uptake peaked in local autumn.
\end{abstract}

KEY WORDS: Urea concentration · Prochlorococcus $\cdot$ Seasonal variability $\cdot$ Atlantic Meridional Transect · Urea uptake

Resale or republication not permitted without written consent of the publisher

\section{INTRODUCTION}

In the surface waters of the open ocean dissolved organic nitrogen (DON) is typically present at concentrations 2 to 3 orders of magnitude greater than those of inorganic forms (Vidal et al. 1999, Bronk 2002). Comprehensive reviews of DON literature by Antia et al. (1991), Bronk (2002) and Bronk et al. (2007) provide considerable insight into the nature of the DON pool, revealing both labile (biologically accessible) and refractory (biologically inaccessible) compounds to be present. These same reviews, which highlight the importance of the smaller labile fraction for phytoplankton production, also reveal the low number of observations from the open ocean presented to date. In part, the limited information available on labile DON stems from the historical assumption that all DON is refractory. This is clearly not the case, as it has been known for some time that urea, a labile constituent of DON, is both actively produced and consumed within the euphotic zone (Remsen 1971, McCarthy 1972, McCarthy \& Kamykowski 1972, Eppley et al. 1973).

There are 3 commonly cited sources of urea: (1) zooplankton and fish excretion (Eppley et al. 1973, Conover \& Gustavson 1999, Hammerschlag 2006), (2) bacterial degradation of dissolved organic matter (Price et al. 1985, Cho et al. 1996, Berman et al. 1999) and (3) microheterotrophic regeneration (Slawyk et al. 1990, L'Helguen et al. 2005), though the relative contribution from each process is far from clear and 
appears highly variable across aquatic systems. Early studies on urea uptake suggested that phytoplankton were the major consumers of urea (e.g. Remsen 1971, McCarthy 1972) and following a study by Wheeler \& Kirchman (1986), who investigated urea usage by marine bacteria, it became widely assumed that bacterial uptake of urea was negligible (Price \& Harrison 1988, Tamminen \& Irmisch 1996, Kirchman 2000, Bronk 2002). However, the validity of this assumption remains unclear due to opposing conclusions drawn from marine and freshwater studies and variable results from estuarine locations (Cho et al. 1996, Kirchman 2000, Jørgensen 2006, Bronk et al. 2007). Urea is therefore typically viewed as a nitrogen source for phytoplankton and is certainly well documented as such in coastal and estuarine environments (Harrison et al. 1985, Tamminen \& Irmisch 1996, Lomas et al. 2002). In these waters, seasonal trends in urea concentration have been observed (Lomas et al. 2002), though this seasonality may reflect the worldwide increase of urea-based fertilizers (Glibert et al. 2006, Bronk et al. 2007). Seasonal changes in urea concentration are rarely reported for the open ocean but the data reported by Eppley et al. 1977 (their Table 2) reveal higher mean integrated urea concentrations in late spring in the North Pacific Subtropical Gyre than during any other season, suggesting that seasonal changes in concentration may be present.

Studies that specifically investigate urea uptake and the role of urea in supporting primary production within the open ocean are limited (e.g. McCarthy 1972, Eppley et al. 1973, Herbland 1976, Price \& Harrison 1988, Kavakina \& Sapozhnikov 1995). In part this is due to the variable importance different studies ascribe to urea, but mainly this has resulted from greater interest in ammonium $\left(\mathrm{NH}_{4}{ }^{+}\right)$and nitrate $\left(\mathrm{NO}_{3}{ }^{-}\right)$cycling. In reviewing published oceanic urea uptake rates, Kudela \& Cochlan (2000) revealed that urea uptake could represent up to $57 \%$ of total nitrogen uptake (total $\rho \mathrm{N}=\rho \mathrm{NO}_{3}{ }^{-}+\rho \mathrm{NH}_{4}{ }^{+}+$purea), suggesting a dominant role for urea as previously inferred by Wafar et al. (1995) and reflected in its influence on the $f$-ratio (Eppley \& Peterson 1979). However, the variable uptake rates derived from all 3 major oceanic basins resulted in a mean contribution of purea to total $\rho \mathrm{N}$ within the open ocean studies of $23 \%$; we note that these rate measurements are skewed towards the North Pacific. In comparison, the mean contribution of purea to total $\rho \mathrm{N}$ in coastal, upwelling, estuarine and polar-based studies was $24,27,31$ and $24 \%$, respectively. Collectively therefore, urea provides 23 to $31 \%$ of total $\rho \mathrm{N}$ by phytoplankton in any particular aquatic environment. A similar analysis by Bronk (2002) concluded that mean urea uptake in the open ocean represented $19 \%$ of total $\mathrm{N}$ uptake. Occasionally, and irre- spective of sampling environment, it is not uncommon to find contributions of purea to total $\rho \mathrm{N}$ that exceed $50 \%$ (Glibert et al. 1991, Watts \& Owens 1999, Varela et al. 2005). It is possible that these higher contributions reflect specific circumstances such as a time-limited period of increased urea availability or the dominant presence of certain phytoplankton species. Urea may therefore be considerably more important than is generally assumed, but our knowledge of the factors influencing its importance is limited, in part because of the complication of its place within the DON pool.

The observations of high, although variable, contributions of purea to total $\rho \mathrm{N}$ tentatively support the contention that organic nitrogen is of considerable importance for primary production in the subtropical ocean (Zubkov et al. 2003, Roussenov et al. 2006, Casey et al. 2007). Recently, the first meridional analysis of urea concentrations and uptake rates within the Atlantic Ocean revealed that purea represented up to $80 \%$ of total $\rho \mathrm{N}$ along a transect from the UK to Uruguay (Varela et al. 2005). As with previous studies, purea contributions were highly variable, ranging from 19 to $80 \%$ of total $\rho \mathrm{N}$, but they were significantly higher within the biogeographical provinces of the South Atlantic, as defined by Longhurst (1998). Evidence has also recently emerged suggesting that Prochlorococcus spp., the most dominant picoplankton in the subtropical ocean, subsist almost exclusively on urea (Casey et al. 2007), a fact that may go someway toward explaining its dominance in the subtropical ocean (Zubkov et al. 2003).

In light of the importance of urea in the South Atlantic (Varela et al. 2005), its apparent importance for Prochlorococcus productivity (Casey et al. 2007), and recent proposals to aid carbon sequestration by fertilizing the subtropical oceans with urea (Young 2007), we examine the role of urea within the Atlantic Ocean between $50^{\circ} \mathrm{N}$ and $50^{\circ} \mathrm{S}$.

\section{MATERIALS AND METHODS}

The observations reported here were collected during 2 meridional transects of the Atlantic Ocean aboard the RRS 'James Clark Ross' (see Robinson et al. 2006), between 12 May and 17 June 2003 (Atlantic Meridional Transact cruise 12, AMT12) and between 28 April and 1 June 2004 (AMT14). For comparative purposes we also include results from AMT11 (12 September to 11 October 2000), previously reported by Varela et al. (2005) (Fig. 1). Cruises AMT12 and AMT14 were northbound, occurring during the boreal (Northern Hemisphere) spring, whilst AMT11 was southbound during the boreal autumn. During AMT11 sampling was conducted at 3 irradiance depths corre- 


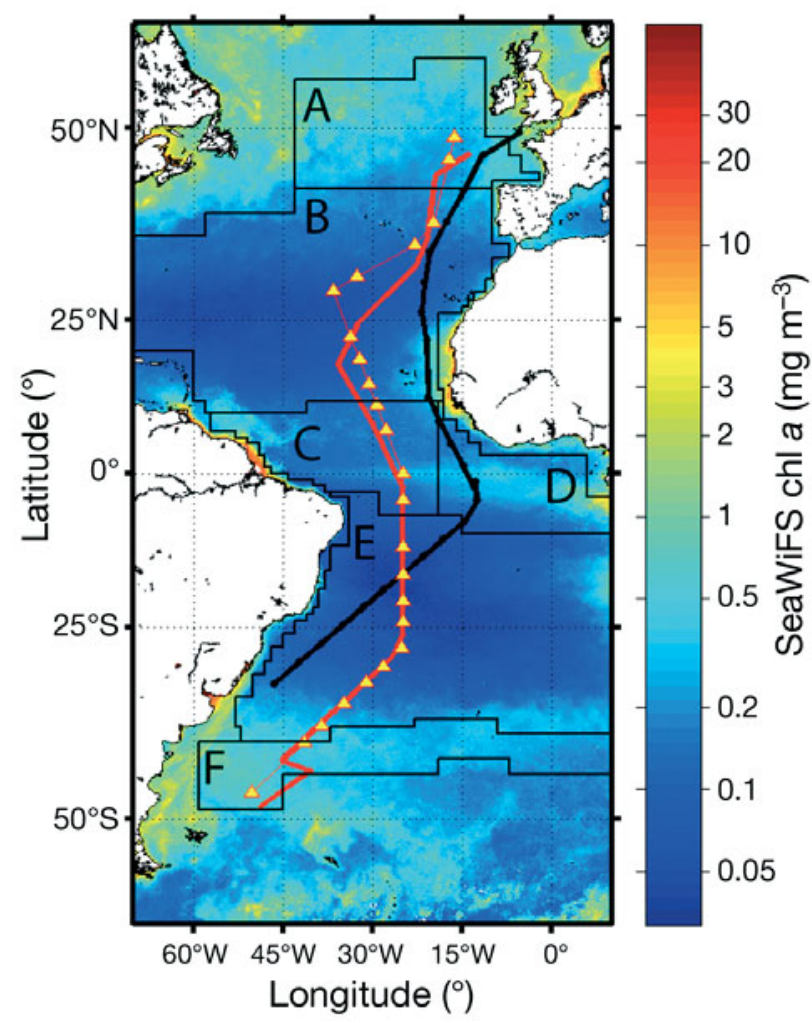

Fig. 1. Map of the Atlantic Meridional Transect (AMT) survey region. Shown are cruise tracks and pre-dawn sampling locations for cruises AMT11 (thick black line), AMT12 (thick red line), and AMT14 (thin red line with yellow triangles). The southbound (boreal autumn) cruise (AMT11) is shown in black and northbound (boreal spring) cruises (AMT12 and AMT14) are shown in red. The underlying chl a image is the SeaWiFS 2006 yearly mean shown to highlight typical latitudinal differences in productivity along the cruise tracks. Biogeographical provinces referred to in text are (A) North Atlantic Drift (NADR), (B) North Atlantic Subtropical (NAST), (C) Western Tropical Atlantic (WTRA), (D) Eastern Tropical Atlantic (ETRA), (E) South Atlantic (SATL) and (F) Southern Subtropical Convergence (SSTC)

sponding to 100,7 and $1 \%$ of surface irradiance. During AMT12 and AMT14, water samples were collected from 5 depths corresponding to irradiances representing surface (97), 55, 33, 14, and $1 \%$ surface irradiance from pre-dawn casts of a Seabird 911+ CTD/Niskin rosette system. Optical depths were identified from mid-morning $(1100 \mathrm{~h})$ optical casts conducted the previous day and by assuming the $1 \%$ irradiance depth was approximated by the fluorescence maximum (Agusti \& Duarte 1999).

Ambient urea concentrations. Water samples were collected in triplicate in sterile polyethylene scintillation vials and frozen at $-20^{\circ} \mathrm{C}$ prior to analysis back in the laboratory. Price \& Harrison (1987) and Cochlan \& Bronk (2001) have both previously concluded that freezing to preserve urea samples is a robust proce- dure with little or no sample degradation over time. After thawing and returning to room temperature, urea concentrations were determined using the method of Goeyens et al. (1998), a room temperature variant of a diacetlymonoxime method described by Mulvenna \& Savidge (1992). Urea concentrations reported by Varela et al. (2005) for AMT11 were obtained following similar storage and identical methodologies, and are thus considered directly comparable.

Urea uptake rates. Water samples for measuring whole community urea-N uptake were carefully measured into 2 l Nalgene polycarbonate bottles, inoculated with ${ }^{15} \mathrm{~N}$ labelled urea (>99\% purity, CIL Laboratories) and placed into simulated in situ perspex incubators within $1 \mathrm{~h}$ of collection. The incubation tubes were covered with neutral density filters (Misty Blue [061] and Neutral Density Grey [210 ND], Lee Filters) to reconstruct water column light attenuation (97, $55,33,14$, and $1 \%$ incoming irradiance) and to remove red light. Incubator temperatures were regulated to mimic the vertical temperature gradient, typically $5^{\circ} \mathrm{C}$ between surface and thermocline waters. The 4 surface incubators (97 to $14 \%$ ) were flushed with surface seawater collected via the ship's underway system whilst the deeper thermocline sample (1\%) was flushed with chilled freshwater to within $\pm 2{ }^{\circ} \mathrm{C}$ of in situ temperatures.

As ambient urea concentrations were determined post-cruise, ${ }^{15} \mathrm{~N}$ labelled urea additions were made without prior knowledge of urea concentrations. We mitigated this potential problem in 2 ways, firstly with prior reference to the literature and secondly by assuming urea concentrations were approximately equal to $\mathrm{NH}_{4}{ }^{+}$concentrations, which were measured onboard ship during all cruises. The literature assessment revealed a wide range of observed concentrations, including more generalised statements regarding typical concentrations being $\sim 500$ nmol urea $\mathrm{l}^{-1}$ (Herbland 1976, Price \& Harrison 1987) and $300 \mathrm{nmol}$ urea $l^{-1}$ (Bronk 2002). In one extreme case concentrations $<15 \mathrm{nmol}$ urea $\mathrm{l}^{-1}$ were observed (Metzler et al. 1997) but reported oceanic concentrations were generally $>150 \mathrm{nmol}$ urea $\mathrm{l}^{-1}$. Assuming therefore that urea could be almost an order of magnitude more abundant in the open ocean than $\mathrm{NH}_{4}{ }^{+}$, which is typically $<30 \mathrm{nmol} \mathrm{l}^{-1}$ (Rees et al. 2006), we felt confident that linking urea to $\mathrm{NH}_{4}{ }^{+}$concentrations would allow small non perturbing ${ }^{15} \mathrm{~N}$ urea additions to be made to the incubation bottles. Thus, during AMT12, urea additions ranged from 10 to $50 \mathrm{nmol} \mathrm{l}^{-1}$ and resulted in mean aqueous enrichments relative to actual urea concentrations of $14 \%$ (range 2 to $88 \%$ ). During AMT14, ${ }^{15} \mathrm{~N}$ additions were reduced to 1 to $28 \mathrm{nmol} \mathrm{l}^{-1}$, resulting in a mean aqueous enrichment of $7 \%$ (range 1 to $47 \%$ ). Varela et al. (2005) report that during AMT11 a 
constant ${ }^{15} \mathrm{~N}$ addition of $100 \mathrm{nmol} \mathrm{l}^{-1}$ was added to $250 \mathrm{ml}$ polycarbonate bottles, resulting in enrichments of 0.3 to $97 \%$.

All samples from AMT12 and AMT14 were incubated from local dawn to dusk (approximately 10 to $12 \mathrm{~h}$ ). Samples from AMT11 were incubated for 2 to $3 \mathrm{~h}$ only. In all cases particulate nitrogen was recovered on pre-ashed $\left(450^{\circ} \mathrm{C}\right.$ for $\left.>6 \mathrm{~h}\right)$ Whatman $\mathrm{GF} / \mathrm{F}$ filters under gentle vacuum pressure. Filters were stored frozen at $-20^{\circ} \mathrm{C}$ until later isotopic analysis. Uptake rates were calculated using Eq. (5) of Dugdale \& Wilkerson (1986) and are reported in units of nmol $\mathrm{N}$ $\mathrm{l}^{-1} \mathrm{~h}^{-1}$ or scaled to photic day length when integrated. We note here that the results are uncorrected for isotopic dilution effects, a methodological issue requiring further investigation.

\section{RESULTS}

\section{Ambient urea concentrations}

Euphotic zone ambient urea concentrations measured during all 3 cruises were typically between 150 and 350 nmol urea $\mathrm{l}^{-1}$, but sometimes lower, or as high as 750 and 1720 nmol urea $\mathrm{l}^{-1}$ during AMT12 and AMT11, respectively. Individual vertical profiles of urea concentration proved to be highly variable, with profiles exhibiting (1) surface maxima (<15 m), (2) subsurface maxima (15 to $40 \mathrm{~m}$ ), or less frequently, (3) a steady increase with depth. There was no geographical consistency in the distribution of these profile shapes and urea was tremendously variable, with even neighbouring stations exhibiting very different profiles. Urea standing stocks integrated to the base of the euphotic zone (1\% irradiance) are shown in Fig. 2,
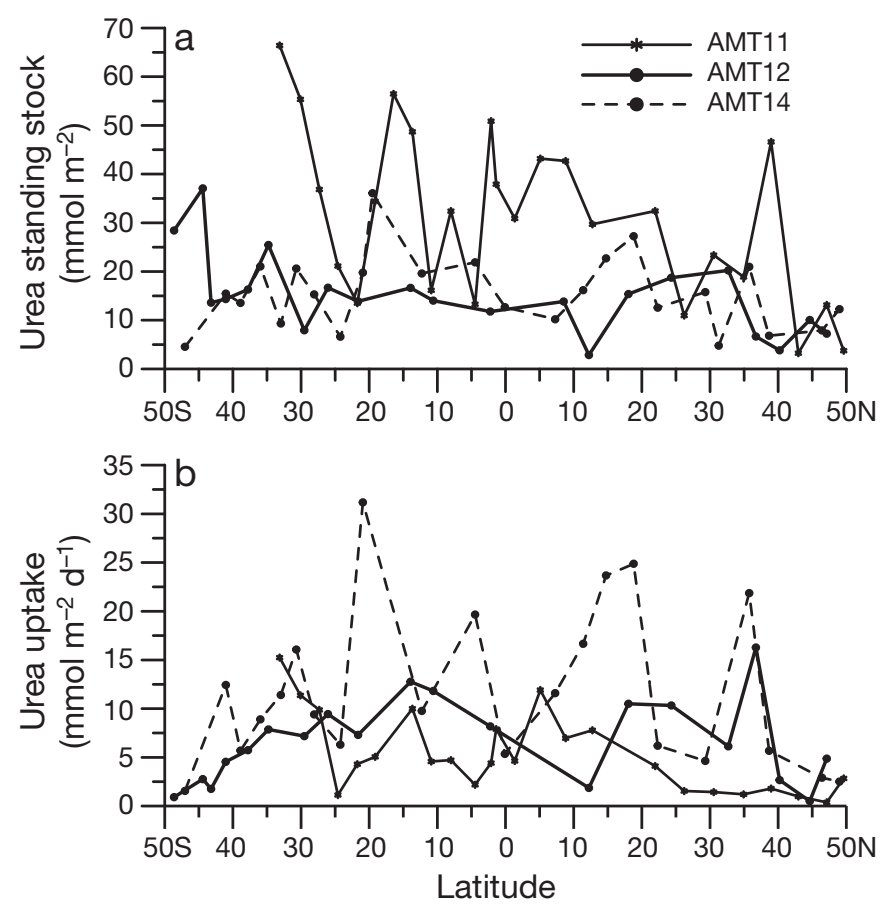

Fig. 2. Latitudinal patterns in (a) integrated urea standing stocks and (b) integrated urea uptake rates. All integrations have been performed to the $1 \%$ irradiance depth

with biogeographical province means presented in Table 1 . The results from the 3 cruises are generally comparable and reveal euphotic zone standing stocks of 10 to $20 \mathrm{mmol}$ urea $\mathrm{m}^{-2}$ with maximum standing stocks in excess of $30 \mathrm{mmol}$ urea $\mathrm{m}^{-2}$ identified in the South Atlantic (SATL) and Southern Subtropical Convergence (SSTC) provinces during AMT11 and AMT14, and AMT12, respectively. The results collected during AMT11 reveal that urea concentrations

Table 1. Standing stocks of urea $\left(\mathrm{mmol} \mathrm{m}^{-2}\right)$ in the biogeochemical provinces of the Atlantic Ocean as measured during 3 AMT cruises. All concentrations have been integrated to the $1 \%$ irradiance horizon (mean integration depths shown in Table 2). AMT11 results recalculated from the in vitro data of Varela et al. (2005). Provinces as shown and defined in Fig. 1, with the addition of Canaries Upwelling (CNRY), and Brazilian Shelf (BRAZ). The timing of each cruise is given relative to the Northern Hemisphere (boreal) season which means that southern provinces were sampled during the opposing Southern Hemisphere (austral) season. -: no data

\begin{tabular}{|c|c|c|c|c|c|c|c|c|c|}
\hline \multirow[t]{2}{*}{ Province } & \multicolumn{3}{|c|}{$\begin{array}{l}\text { Boreal autumn } 2000 \\
\text { AMT11 }\end{array}$} & \multicolumn{3}{|c|}{$\begin{array}{l}\text { Boreal spring } 2003 \\
\text { AMT12 }\end{array}$} & \multicolumn{3}{|c|}{$\begin{array}{c}\text { Boreal spring } 2004 \\
\text { AMT14 }\end{array}$} \\
\hline & Mean & Range & $\mathrm{n}$ & Mean & Range & $\mathrm{n}$ & Mean & Range & $\mathrm{n}$ \\
\hline NADR & 20.99 & $3.23-46.62$ & 3 & 7.04 & $3.84-10.05$ & 3 & 10.09 & $7.92-12.27$ & 2 \\
\hline NAST & 17.75 & $10.96-23.38$ & 3 & 12.77 & $2.85-20.24$ & 5 & 15.88 & $6.82-27.24$ & 8 \\
\hline CNRY & 31.06 & $29.7-32.42$ & 2 & - & - & - & - & - & - \\
\hline ETRA & 35.90 & $13.3-50.9$ & 7 & - & - & - & - & - & - \\
\hline WTRA & - & - & - & 12.80 & $11.78-13.83$ & 2 & 14.93 & $10.20-21.89$ & 3 \\
\hline SATL & 33.86 & $13.5-56.5$ & 5 & 15.85 & $7.94-25.46$ & 7 & 17.99 & $6.63-36.07$ & 9 \\
\hline SSTC & - & - & - & 23.36 & $13.6-37.07$ & 4 & 10.01 & $4.55-15.48$ & 2 \\
\hline BRAZ & 44.96 & $21.15-66.43$ & 4 & - & - & - & - & - & - \\
\hline
\end{tabular}


were higher along the AMT11 transect than along any of the 2 later transects. This difference, despite identical methodologies, frequently results in urea standing stocks elevated by a factor of 2 to 3 during AMT11 and may reflect differences in cruise track (Fig. 1).

\section{Urea uptake}

When all uptake data from the 3 cruises were pooled together, we found that urea uptake rates ranged from

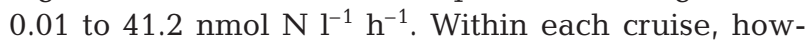
ever, we found uptake rates ranged from 0.01 to 23.8,

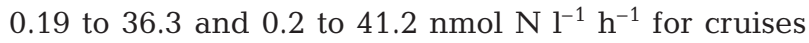
AMT11, AMT12 and AMT14, respectively. Uptake

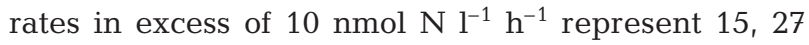
and $34 \%$ of observations, respectively, for these same cruises.

In an analogous manner to the vertical profiles of urea, uptake rates were typically highest in surface $(<15 \mathrm{~m})$ or near-surface waters (generally $<35 \mathrm{~m})$, with deeper maxima (generally $\sim 45 \mathrm{~m}$ but occasionally to $\sim 90 \mathrm{~m}$ ) observed in subtropical latitudes (15 to $30^{\circ}$ N/S). Irrespective of sampling location, uptake rates decreased rapidly with depth below the uptake maxima, thus predominately confining urea uptake to the surface ocean. Integrated uptake rates (Fig. 2) were highly variable with latitude but showed a tendency to peak between $30^{\circ} \mathrm{S}$ and $30^{\circ} \mathrm{N}$. The highest integrated uptake rate of $31.2 \mathrm{mmol} \mathrm{N} \mathrm{m}^{-2} \mathrm{~d}^{-1}$ was observed in the SATL province during AMT14. When spatially averaged (Table 2), integrated urea uptake rates reveal a wide range of values for each province, with uptake rates varying by up to a factor of 10 within any particular province, even within the same cruise.

Chlorophyll-normalised urea uptake rates were calculated for each discrete sample and a water column average for each station determined before averaging over the province domains (Table 3 ). This revealed that chlorophyll-normalised uptake rates were very similar during AMT12 and AMT14 and larger than those for AMT11 in most provinces. The normalised uptake rates calculated for AMT12 and AMT14 are similar to estimates derived from studies conducted in the North Pa-

Table 2. Urea-N uptake rates $\left(\mathrm{mmol} \mathrm{N} \mathrm{m} \mathrm{N}^{-2} \mathrm{~d}^{-1}\right.$ in the biogeochemical provinces of the Atlantic Ocean as measured during 3 AMT cruises. All results have been integrated to the $1 \%$ irradiance horizon. AMT11 results recalculated from the in vitro data of Varela et al. (2005). Provinces as shown and defined in Fig. 1 with the addition of Canaries Upwelling (CNRY), and Brazilian Shelf (BRAZ). The timing of each cruise is given relative to the Northern Hemisphere (boreal) season, which means that southern provinces were sampled during the opposing Southern Hemisphere (austral) season. -: no data

\begin{tabular}{|c|c|c|c|c|c|c|c|c|c|c|c|c|}
\hline \multirow[t]{2}{*}{ Province } & \multicolumn{3}{|c|}{$\begin{array}{l}\text { Boreal autumn } 2000 \\
\text { AMT11 }\end{array}$} & \multirow[b]{2}{*}{$\mathrm{n}$} & \multicolumn{4}{|c|}{$\begin{array}{c}\text { Boreal spring } 2003 \\
\text { AMT12 }\end{array}$} & \multicolumn{4}{|c|}{$\begin{array}{c}\text { Boreal spring } 2004 \\
\text { AMT14 }\end{array}$} \\
\hline & Mean & Range I & Int depth (m) & & Mean & Range & Int depth (m) & $\mathrm{n}$ & Mean & Range & Int depth (m) & $\mathrm{n}$ \\
\hline NADR & 1.05 & $0.37-1.79$ & 63 & 3 & 2.67 & $0.5-4.86$ & 40 & 3 & 2.71 & $2.51-2.91$ & 48 & 2 \\
\hline NAST & 1.39 & $1.2-1.54$ & 113 & 3 & 9.01 & $1.85-16.27$ & 102 & 5 & 14.79 & $4.63-24.87$ & 113 & 7 \\
\hline CNRY & 5.95 & $4.11-7.78$ & 80 & 2 & - & - & & - & - & - & - & - \\
\hline ETRA & 6.10 & $2.18-11.91$ & 77 & 7 & - & - & & - & - & - & - & - \\
\hline WTRA & - & - & - & - & 8.17 & - & 62 & 1 & 12.20 & $5.3-19.65$ & 70 & 3 \\
\hline SATL & 5.98 & $4.3-9.99$ & 134 & 5 & 8.87 & $5.73-12.77$ & 106 & 7 & 12.34 & $5.7-31.17$ & 99 & 8 \\
\hline SSTC & - & - & - & - & 2.49 & $0.91-4.54$ & 94 & 4 & 6.99 & $1.56-12.42$ & 48 & 2 \\
\hline BRAZ & 9.40 & $1.14-15.24$ & 99 & 4 & - & - & - & - & - & - & - & - \\
\hline
\end{tabular}

Table 3. Column averaged chlorophyll normalised urea uptake rates (mg N per $\mathrm{mg} \mathrm{chl}$ a) for the provinces shown and identified in Fig. 1 with the addition of Canaries Upwelling (CNRY), and Brazilian Shelf (BRAZ). -: no data

\begin{tabular}{|c|c|c|c|c|c|c|c|c|c|}
\hline \multirow[t]{2}{*}{ Province } & \multicolumn{3}{|c|}{$\begin{array}{l}\text { Boreal autumn } 2000 \\
\text { AMT11 }\end{array}$} & \multicolumn{3}{|c|}{$\begin{array}{c}\text { Boreal spring } 2003 \\
\text { AMT12 }\end{array}$} & \multicolumn{3}{|c|}{$\begin{array}{c}\text { Boreal spring } 2004 \\
\text { AMT14 }\end{array}$} \\
\hline & Mean & Range & $\mathrm{n}$ & Mean & Range & $\mathrm{n}$ & Mean & Range & $\mathrm{n}$ \\
\hline NADR & 0.16 & $0.07-0.33$ & 3 & 0.56 & $0.04-0.9$ & 3 & 0.44 & $0.37-0.5$ & 2 \\
\hline NAST & 0.22 & $0.15-0.3$ & 3 & 1.77 & $0.55-4.07$ & 5 & 2.06 & $0.98-3.28$ & 7 \\
\hline CNRY & 0.51 & $0.38-0.65$ & 2 & - & - & - & - & - & - \\
\hline ETRA & 0.38 & $0.14-1.11$ & 7 & - & - & - & - & - & - \\
\hline WTRA & - & - & - & 2.51 & - & & 1.56 & $0.75-2.07$ & 3 \\
\hline SATL & 0.69 & $0.33-1.11$ & 4 & 1.77 & $0.71-3.45$ & 7 & 1.6 & $0.7-2.49$ & 8 \\
\hline SSTC & - & - & - & 0.19 & $0.05-0.39$ & 4 & 0.6 & - & 1 \\
\hline BRAZ & 0.42 & $0.07-0.65$ & 4 & - & - & - & - & - & - \\
\hline
\end{tabular}


cific subtropical gyre (Table 4), but are considerably lower than estimates derived from work in the Sargasso Sea (Price \& Harrison 1988). The similar but notably higher chlorophyll-normalised uptake rates obtained during AMT12 and AMT14, relative to AMT11, are suggestive in that they indicate a greater importance for urea towards the centre of the northern subtropical gyre than towards the eastern edge of the same gyre where AMT11 sampled (Fig. 1). A similar increase in importance can be seen in the SATL province.

\section{Provincial trends}

The integrated biogeographical province means of urea concentration (Table 1) and urea uptake (Table 2) reveal considerable variability within all provinces, both within and between individual cruises. From a statistical viewpoint (ANOVA), none of the results from any single cruise are significantly different from those of any other in any of the provinces. However, when the data from the 3 cruises are regrouped into the 2 seasonal periods that they represent, significant seasonal differences are seen, notably within the subtropical and tropical provinces (Fig. 3).

The most significant seasonal difference we observed is in urea uptake rates within the North Atlantic Subtropical (NAST) province, where we found urea uptake to be over 9 times larger during boreal spring (12.39 mmol $\mathrm{N} \mathrm{m}^{-2} ; \mathrm{p}<0.001, \mathrm{df}=12$ ) than during autumn $\left(1.28 \mathrm{mmol} \mathrm{N} \mathrm{m}^{-2}\right)$. However, despite this very large difference in uptake rates, integrated urea concentrations were not significantly different between the seasons, being a more modest $21 \%$ larger during the boreal autumn (17.75 mmol urea $\mathrm{m}^{-2}$ ) relative to the boreal spring (14.68 $\mathrm{mmol}$ urea $\mathrm{m}^{-2}$ ). There is thus an apparent seasonal offset in the timing of maximum urea availability and maximum urea uptake in this province, with urea uptake apparently more important during spring.

Observations from the Western Tropical Atlantic (WTRA) province were not made during AMT11 as the
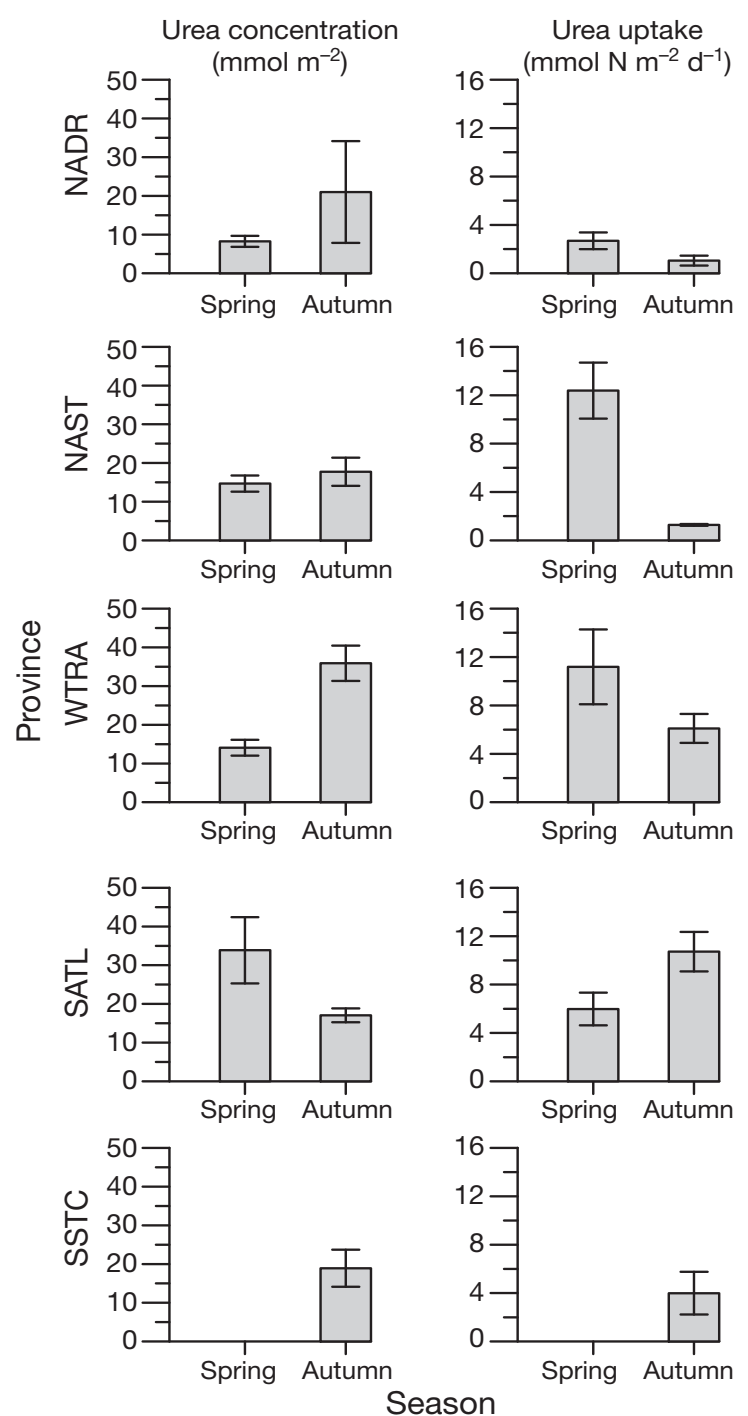

Fig. 3. Mean $( \pm \mathrm{SE})$ seasonally integrated euphotic zone ambient urea concentration and urea uptake rates for selected biographical provinces, as shown and defined in Fig. 1. The data for the Southern Hemisphere provinces have been seasonally adjusted such that the timing of observations is now shown relative to the Southern Hemisphere season for the provinces and not relative to the departure season of the cruise
Table 4. Literature estimates of chlorophyll-normalised urea uptake rates (mg N $\mathrm{mg}^{-1} \mathrm{chl}$ a) for comparable regions

\begin{tabular}{|c|c|c|c|}
\hline Region & Range & $\mathrm{n}$ & Study \\
\hline N. Pacific subtropical gyre & $0.22-6.65^{\mathrm{a}}$ & 14 & Eppley et al. (1973) \\
\hline N. Pacific subtropical gyre & $0.09-4.84^{\mathrm{a}}$ & 19 & Eppley et al. (1977) \\
\hline N. Pacific subtropical gyre & $0.02-0.4^{\mathrm{a}}$ & 18 & Kanda et al. (1985) \\
\hline Sargasso Sea & $0.66-25.01^{\mathrm{a}}$ & 18 & Price and Harrison (1988) \\
\hline S. Atlantic (BRAZ province) & $0.11-0.34^{\mathrm{b}}$ & 2 & Metzler et al. (1997) \\
\hline
\end{tabular}

cruise transect passed through the Eastern Tropical Atlantic (ETRA) province instead. We therefore combine the results from these 2 neighbouring equatorial provinces in our assessment. The low-latitude position of the WTRA province would ordinarily argue against a strong seasonal signal in phytoplankton-related parameters, as irradiance levels are permanently high. Despite this, mean integrated urea concentrations in the tropics were highest during the boreal 
autumn (35.9 mmol urea $\mathrm{m}^{-2}$ ), being more than twice as high as the boreal spring concentration $(14.08 \mathrm{mmol}$ urea $\mathrm{m}^{-2}$ ). This difference was significant $(\mathrm{p}<0.01$, df $=8$ ). However, despite the significant seasonal difference in ambient urea concentration and an $83 \%$ increase in urea uptake during the boreal spring relative to the boreal autumn period in this province, the difference in uptake rates was not significant.

In the SATL province, mean integrated urea concentrations are greatest during the austral spring (boreal autumn, $33.86 \mathrm{mmol}$ urea $\mathrm{m}^{-2}$ ), when concentrations were almost exactly twice as high as during the austral autumn (boreal spring, $17.05 \mathrm{mmol}$ urea $\left.\mathrm{m}^{-2}\right)(\mathrm{p}<0.1$, $\mathrm{df}=4$, marginally significant). Seasonality in the uptake rates for this province is also apparent, with the austral autumn uptake rate of $10.72 \mathrm{mmol} \mathrm{N} \mathrm{m}^{-2} \mathrm{~d}^{-1}$ being $79 \%$ larger $(\mathrm{p}<0.05, \mathrm{df}=13)$ relative to the mean austral spring rate $\left(5.98 \mathrm{mmol} \mathrm{N} \mathrm{m}^{-2} \mathrm{~d}^{-1}\right)$.

The 2 temperate latitude provinces, where one might assume a greater seasonal signal to be found, were harder to quantify. Within the northern North Atlantic Drift (NADR) province, differences between mean boreal autumn and spring integrated urea concentrations differ by a factor of 2.5 , but the difference is not significant. However, uptake rates are significantly different $(p<0.05, d f=6)$, with urea uptake during the spring (2.69 mmol $\mathrm{N} \mathrm{m}^{-2} \mathrm{~d}^{-1}$ ) in excess of 2.5 times higher than the autumn rate $\left(1.05 \mathrm{mmol} \mathrm{N} \mathrm{m}^{-2} \mathrm{~d}^{-1}\right)$. We were unable to investigate trends in the Southern Subtropical Convergence (SSTC) province, due to limited data for this province for the spring period.

\section{DISCUSSION}

In reviewing organic nitrogen distributions within the ocean Bronk (2002) concluded that open ocean urea concentrations were typically $\sim 300 \mathrm{nmol}$ urea $\mathrm{l}^{-1}$, an order of magnitude higher than $\mathrm{NO}_{3}{ }^{-}$or $\mathrm{NH}_{4}{ }^{+}$concentrations, which are typically $<30 \mathrm{nmol} \mathrm{l}^{-1}$ (Rees et al. 2006). Most urea concentrations obtained during the AMT cruises detailed here were within the range of 150 to $350 \mathrm{nmol}$ urea $\mathrm{l}^{-1}$ and therefore close to the Bronk average, although concentrations reported by Bronk (2002) were highly variable, being both substantially lower and higher than our typical range. This observed variability confirms the postulation of Remsen (1971) that the urea pool should be viewed as a result of local formation and utilization processes, and thus is inherently variable in a manner that $\mathrm{NO}_{3}{ }^{-}$, for example, is not. Isolated observations of high urea concentrations have previously been suggested to originate from active biological sources, such as the presence of squid, whales, fish, sharks, seabirds or high zooplankton grazing rates (McCarthy \& Kamykowski
1972, Harrison et al. 1985). With the exception of zooplankton grazing rates (not measured) and the presence of squid, almost all of these suggested sources are probably quantitatively unimportant for the open ocean. Numerous visual sightings in the lower latitudes $\left(\sim 15^{\circ} \mathrm{N}\right.$ to $\left.15^{\circ} \mathrm{S}\right)$ of squid up to $\sim 0.5 \mathrm{~m}$ in length attracted to the ship's lights during pre-dawn sampling suggests a large resident population in the tropical and subtropical ocean (possibly the glassy flying squid Hyaloteuthis pelagica or the orange back squid Sthenoteuthis pteropus; Laptikhovsky et al. 1993, Cherel et al. 2007), so whilst these higher urea concentrations are unusual, they are not improbable. Nevertheless, arguments by Bronk et al. (2007) regarding tightly coupled production and consumption processes leading to consistent DON concentrations are equally applicable here and suggest that the isolated observations of high urea concentrations may be due to temporary imbalances in these coupled processes.

Although the underlying cause(s) of the differences we describe are uncertain, they may reflect seasonal changes in the balance between urea uptake and urea production, but it is not clear from our present dataset which is the more likely. Drawing upon coastal observations, it is encouraging that we find elevated urea concentrations in the temperate North Atlantic, and to a lesser degree in the subtropical North Atlantic, during the boreal autumn period, a pattern similar to that observed by Lomas et al. (2002) for urea in Chesapeake Bay and by Butler et al. (1979) for DON concentrations in the English Channel. The lack of significant seasonal differences in urea concentration within the NADR province, however, may be due to the more dominant role of $\mathrm{NO}_{3}{ }^{-}$and $\mathrm{NH}_{4}{ }^{+}$(Rees et al. 2006, Thomalla et al. 2006), relative to urea in shaping phytoplankton community structure there, relative to community structure (Tarran et al. 2006) and the role of urea in lower latitude waters. Whilst the changes in urea concentration may not be significant in the North Atlantic we do find urea uptake rates to be significantly higher in the NADR and NAST provinces during spring.

We have examined the variability in the contribution urea makes to the DON pool during the cruises in an attempt to estimate whether seasonal differences in this contribution are also present. The DON dataset from AMT11 is discussed in detail in Varela et al. (2005, 2006). The AMT12 and AMT14 dataset will be discussed more fully elsewhere (S. Torres-Valdes unpubl. data), but for completeness we include a brief methodological summary here. Seawater was filtered through combusted $\left(450^{\circ} \mathrm{C}, 4 \mathrm{~h}\right) 47 \mathrm{~mm}$ GF/F filters using an acid-treated $(10 \% \mathrm{HCl}, 24 \mathrm{~h})$ glass filtration unit. Samples were collected in sterile $60 \mathrm{ml}$ polystyrene vials and returned to shore frozen at $-20^{\circ} \mathrm{C}$ for the determination of organic nutrients (Sanders et al. 
2005). Total dissolved nitrogen (TDN) was measured as $\mathrm{NO}_{3}{ }^{-}$after oxidation for $2 \mathrm{~h}$ using a Metrohm 705 UV digester system (Sanders \& Jickells 2000). The DON concentration was calculated by subtracting the inorganic fraction from the TDN concentration. The results of this analysis (Fig. 4) reveal that in $85 \%$ of cases, urea represents $<10 \%(6 \pm 6.6 \%$, mean $\pm \mathrm{SD})$ of the DON pool. Our calculated mean contribution is almost identical to that previously estimated by Bronk (2002) of $5.2 \pm 3.4 \%$. Higher contributions, $>15 \%$, are also present, but although there is no geographical nor depth-related pattern to these observations, higher contributions usually occurred when lower DON concentrations were recorded. We did not observe simultaneously high urea and low DON concentrations, a possible indication that this may rule out bacterial degradation of DON as a source of urea (Price et al. 1985, Cho et al. 1996, Berman et al. 1999).

Other indications that seasonal changes in the balance between uptake and production may be important can be seen in the data. When urea was more plentiful in the NAST and NADR provinces during the boreal autumn, uptake rates were seasonally at their lowest. However, the reverse was true during boreal spring, when urea concentrations were at their lowest and urea uptake was at its highest. This may indicate that in the boreal autumn, degradation or excretion processes that add to the urea pool exceed uptake rates, while in spring, urea uptake rates exceed urea regeneration rates. The SATL province behaves in a similar manner, with urea standing stocks highest during austral spring, concurrent with lower integrated urea uptake rates.

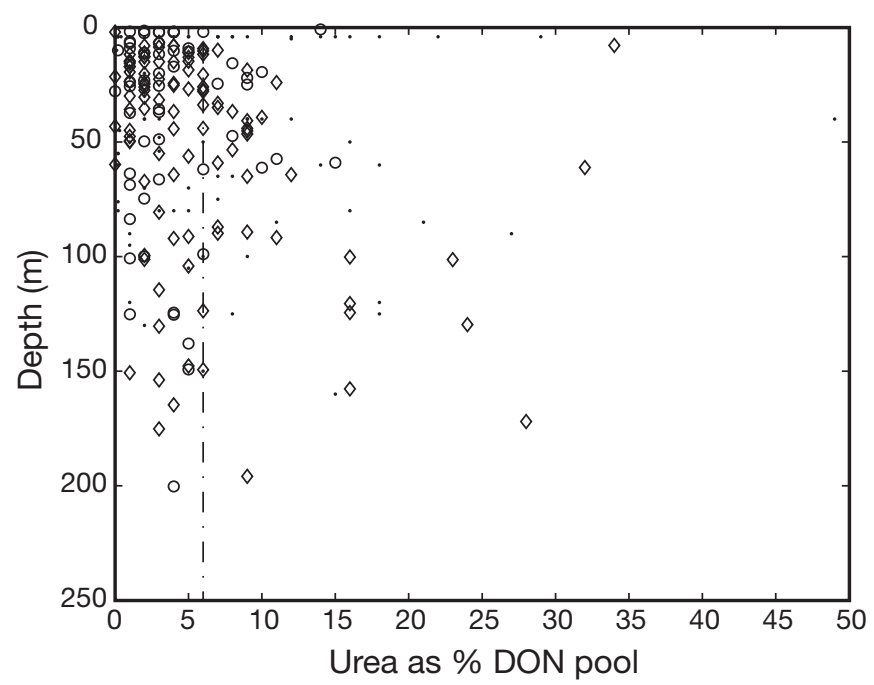

Fig. 4. Urea as a percentage of the dissolved organic nitrogen (DON) pool. Measurements shown are from cruises AMT11 $(\cdot)$, AMT12 $(0)$, AMT14 $(\diamond)$. The vertical dashed line marks the mean contribution urea makes to the DON pool for the entire dataset

\section{Prochlorococcus and urea}

Vertical profiles of urea uptake reveal that the majority of urea uptake occurs in the near surface ocean $(<45 \mathrm{~m})$ and decreases rapidly thereafter. This suggests uptake predominantly by photoautotrophic organisms. Typically, 70 to $90 \%$ of chlorophyll $a$ is found within picoplankton $(<2 \mu \mathrm{m}$ in size) in the subtropical Atlantic (Maranon et al. 2003, Perez et al. 2006, Poulton et al. 2006) and this size fraction is usually dominated by Prochlorococcus in the subtropical oligotrophic ocean (Partensky et al. 1999, Zubkov et al. 2000, Heywood et al. 2006). Over much of the AMT transect, parallels may be drawn between the typical subtropical and dominant distribution of Prochlorococcus, which is often maximal in surface or near surface waters (Heywood et al. 2006) and the shallow nature of urea uptake. As Prochlorococcus is generally thought incapable of utilizing $\mathrm{NO}_{3}^{-}$(Rocap et al. 2003), its nitrogen requirements are thought to be met by alternative sources of recycled nitrogen, such as urea (Zubkov et al. 2003). Indeed, Casey et al. (2007) recently found that urea could contribute 90 to $95 \%$ of Prochlorococcus nitrogen requirements. If one therefore postulates a dominant role for urea in Prochlorococcus production, then seasonal variability in the distribution and uptake of urea might be expected to parallel changes in the distribution of Prochlorococcus. However, Heywood et al. (2006) could find no evidence for any such seasonal variability during AMT12 and AMT14, although Zubkov et al. (2000) clearly identified a seasonal signal in Prochlorococcus distribution during earlier transects of the subtropical Atlantic Ocean.

A qualitative comparison between the Prochlorococcus distribution reported by Heywood et al. (2006) and urea uptake rates for AMT14 reveals intriguing parallels between the 2 (Fig. 5), suggesting that Prochlorococcus distribution controls the pattern in observed urea uptake rates, despite our uptake results representing whole-community uptake. However, linear regression analyses of integrated urea concentration and urea uptake rates against Prochlorococcus abundance, using all available data from AMT12 and AMT14 (the 2 cruises where this was possible) reveal them to be poorly correlated. On a provincial basis, however, positive correlations were found, but with the exception of the WTRA ( $p<0.1$; data not shown) and NAST provinces (Fig. 6) these relationships were not significant. Nevertheless, the significant trends identified within the NAST province (Fig. 6) suggest that $83 \%$ of the variability in urea concentration $(\mathrm{p}<$ 0.01 ) and $78 \%$ of the variability in urea uptake ( $<<$ 0.01 ) can be explained solely by changes in the abundance of Prochlorococcus. There thus appears to be a strong relationship between Prochlorococcus and urea 


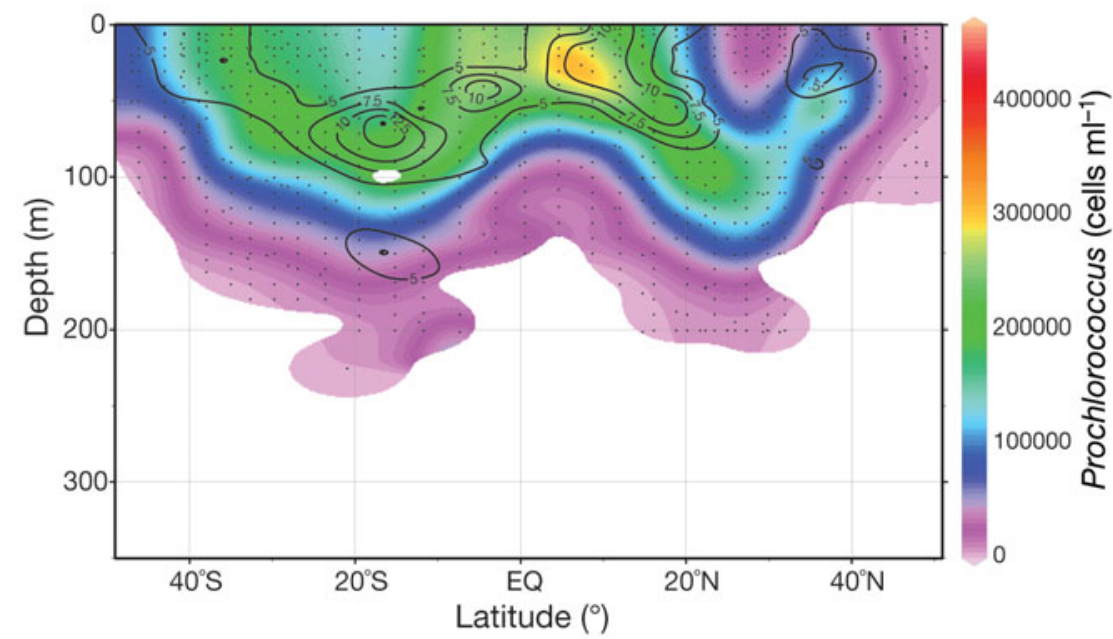

Fig. 5. Relationship between Prochlorococcus abundance (coloured area) and urea uptake (contours: units of nmol $\mathrm{l}^{-1} \mathrm{~h}^{-1}$ ) during AMT14. Contour lines depicting uptake rates $<5 \mathrm{nmol}^{-1} \mathrm{~h}^{-1}$ have been excluded for clarity distribution in the subtropical North Atlantic and to a lesser extent in the equatorial region, but not in the South Atlantic. Interestingly, mean integrated Prochlorococcus abundances during AMT14 were significantly higher $(\mathrm{p}<$ $0.005)$ in the SATL province $\left(2.80 \times 10^{13}\right.$ cells $\mathrm{m}^{-2}$ ) than in the NAST province $\left(1.69 \times 10^{13}\right.$ cell $\left.\mathrm{m}^{-2}\right)$. In contrast, mean integrated urea concentrations and urea uptake rates remain similar between both provinces (Tables 1 \& 2).

\section{Microzooplankton and urea}

Both zooplankton and microzooplankton are known to excrete large quantities of urea (Eppley et al. 1973, Slawyk et al. 1990, Conover \& Gustavson 1999, Wilt-
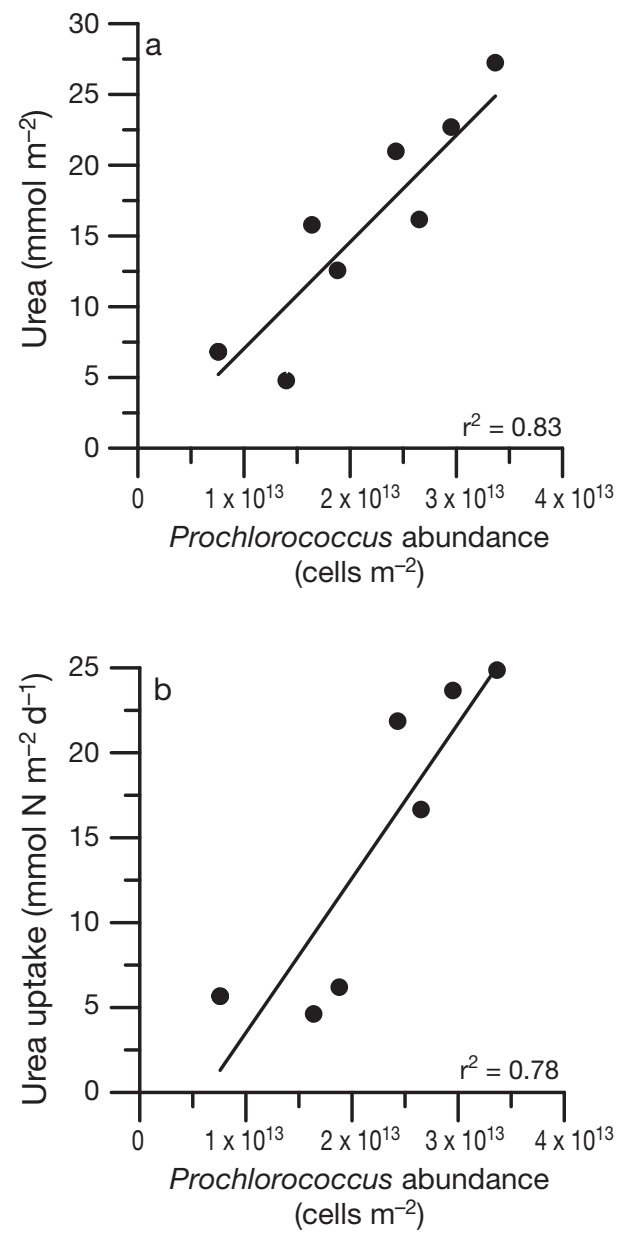

Fig. 6. Results of a linear regression analysis within the North Atlantic Subtropical (NAST) province using the data collected during AMT14 between (a) Prochlorococcus abundance and urea concentrations $(\mathrm{p}<0.01)$ and $(\mathrm{b})$ Prochlorococcus abundance and urea uptake $(\mathrm{p}<0.01)$ shire \& Lampert 1999 L'Helguen et al. 2005) and significant correlations can be identified between zooplankton biomass and urea concentration (Wiltshire \& Lampert 1999). Using microplankton data collected during AMT14 (San Martin et al. 2006), we identified a relationship between the integrated urea concentration and integrated microplankton biomass within the SATL province (Fig. 7), which may imply that components of the microplankton community are important for urea production and, therefore, in moderating the urea concentration. However, as considerable variability characterises our dataset, relationships in the other provinces between microplankton biomass and urea concentration were not significant. Furthermore, because the microplankton biomass estimates com-

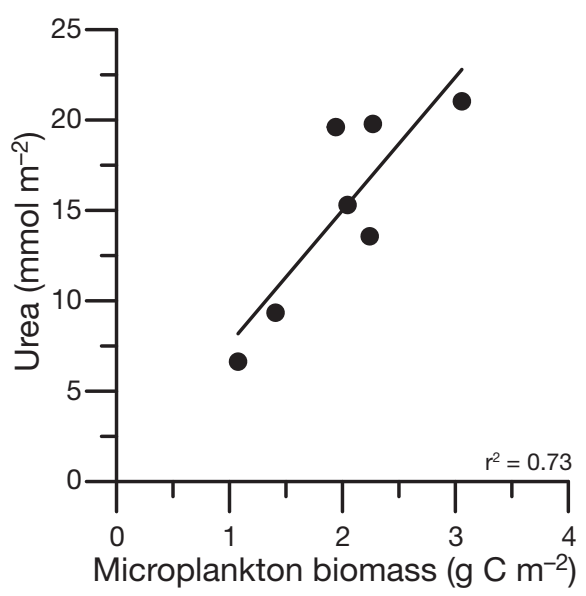

Fig. 7. Identified linear trend within the South Atlantic (SATL) province during AMT14 between integrated urea concentration and integrated zooplankton biomass, equation of the line $y=7.38 x+0.23(p<0.02)$ 
prise both auto- and heterotrophic organisms, we cannot differentiate between urea excretion and uptake in determining the final ambient urea concentrations we observed. Nevertheless, because we found significant relationships in the North and South Atlantic between urea and different size classes of organisms that consume and produce urea respectively, this suggests that there are important differences in the role of urea as inferred from the seasonal assessment of urea concentration and uptake (Fig. 3). This argues for additional coordinated efforts to properly understand the ecological significance of urea in the subtropical ocean ahead of any attempts to purposely release urea as a means of modifying the biological pump to mitigate anthropogenic increases in atmospheric carbon dioxide.

Acknowledgements. We thank M. Bolshaw and G. Taylor for assisting with the mass spectrometer analyses and the officers and crew of the RRS 'James Clark Ross.' Discussions with D. Purdie and comments from 4 anonymous reviewers and the editor aided the preparation of this manuscript. We also thank M. M. Varela, E. San Martin and J. Heywood for making datasets available to us via the British Oceanographic Data Centre. This study was supported by the UK Natural Environment Research Council through the Atlantic Meridional Transect consortium (NER/O/S/2001/00680). This is contribution number 158 of the AMT programme.

\section{LITERATURE CITED}

Agusti S, Duarte CM (1999) Phytoplankton chlorophyll a distribution and water column stability in the Central Atlantic Ocean. Oceanol Acta 22:193-203

Antia NJ, Harrison PJ, Oliveira L (1991) Phycological reviews: the role of dissolved organic nitrogen in phytoplankton nutrition, cell biology, and ecology. Phycologia 30:1-89

Berman T, Bechemin C, Maestrini SY (1999) Release of ammonium and urea from dissolved organic nitrogen in aquatic ecosystems. Aquat Microb Ecol 16:295-302

Bronk DA (2002) Dynamics of DON. In: Hansell DA, Carlson CA (eds) Biogeochemistry of marine dissolved organic matter. Academic Press, San Diego, CA, p 153-247

Bronk DA, See JH, Bradley P, Killberg L (2007) DON as a source of bioavailable nitrogen for phytoplankton. Biogeosciences 4:283-296

Butler EI, Knox S, Liddicoat MI (1979) The relationship between inorganic and organic nutrients in seawater. J Mar Biol Assoc UK 59:239-250

Casey JR, Lomas MW, Mandecki J, Walker DE (2007) Prochlorococcus contributes to new production in the Sargasso Sea deep chlorophyll maximum. Geophys Res Lett 34:L10604. doi:10.1029/2006GL028725

Cherel Y, Sabatie R, Potier M, Marsac F, Menard F (2007) New information from fish diets on the importance of glassy flying squid (Hyaloteuthis pelagica) (Teuthoidea: Ommastrephidae) in the epipelagic cephalopod community of the tropical Atlantic Ocean. Fish Bull (Wash DC) 105:147-152

> Cho BC, Park MG, Shim JH, Azam F (1996) Significance of bacteria in urea dynamics in coastal surface waters. Mar Ecol Prog Ser 142:19-26

Cochlan WP, Bronk DA (2001) Nitrogen uptake kinetics in the
Ross Sea, Antarctica. Deep-Sea Res II 48:4127-4153

Conover RJ, Gustavson KR (1999) Sources of urea in Arctic seas: Zooplankton metabolism. Mar Ecol Prog Ser 179: $41-54$

Dugdale RC, Wilkerson FP (1986) The use of ${ }^{15} \mathrm{~N}$ to measure nitrogen uptake in eutrophic oceans; experimental considerations. Limnol Oceanogr 31:673-689

Eppley RW, Peterson BJ (1979) Particulate organic matter flux and planktonic new production in the deep ocean. Nature 282:677-680

Eppley RW, Renger EH, Venrick EL, Mullin MM (1973) A study of plankton dynamics and nutrient cycling in the central gyre of the North Pacific Ocean. Limnol Oceanogr 18:534-551

Eppley RW, Sharp JH, Renger EH, Perry MJ, Harrison WG (1977) Nitrogen assimilation by phytoplankton and other microorganisms in the surface waters of the central North Pacific Ocean. Mar Biol 39:111-120

Glibert PM, Garside C, Fuhrman JA, Roman MR (1991) Timedependent coupling of inorganic and organic nitrogen uptake and regeneration in the plume of the Chesapeake Bay estuary and its regulation by large heterotrophs. Limnol Oceanogr 36:895-909

Glibert PM, Harrison J, Heil C, Seitzinger S (2006) Escalating worldwide use of urea - a global change contributing to coastal eutrophication. Biogeochemistry 77:441-463

> Goeyens L, Kindermans N, Abu Yusuf M, Elskens M (1998) A room temperature procedure for the manual determination of urea in seawater. Estuar Coast Shelf Sci 47:415-418

Hammerschlag N (2006) Osmoregulation in elasmobranches: a review for fish biologists, behaviourists and ecologists. Mar Freshw Behav Physiol 39:209-228

- Harrison WG, Head EJH, Conover RJ, Longhurst AR, Sameoto DD (1985) The distribution and metabolism of urea in the eastern Canadian Arctic. Deep-Sea Res 32: 23-42

> Herbland A (1976) In situ utilization of urea in the euphotic zone of the tropical Atlantic. J Exp Mar Biol Ecol 21:269-277

> Heywood JL, Zubkov MV, Tarran GA, Fuchs BM, Holligan PM (2006) Prokaryoplankton standing stocks in oligotrophic gyre and equatorial provinces of the Atlantic Ocean: Evaluation of inter-annual variation. Deep-Sea Res II 53:1530-1547

Jørgensen NOG (2006) Uptake of urea by estuarine bacteria. Aquat Microb Ecol 42:227-242

Kanda J, Saino T, Hattori A (1985) Nitrogen uptake by natural populations of phytoplankton and primary production in the Pacific Ocean: regional variability of uptake capacity. Limnol Oceanogr 30:987-999

Kavakina SV, Sapozhnikov VV (1995) Major patterns of urea distribution in the Bering Sea and its role in the nitrogen cycle. Oceanology (Mosc) 33:768-773

Kirchman DL (2000) Uptake and regeneration of inorganic nutrients by marine heterotrophic bacteria. In: Kirchman DL (ed) Microbial ecology of the ocean. Wiley-Liss, New York, p 261-288

Kudela RM, Cochlan WP (2000) Nitrogen and carbon uptake kinetics and the influence of irradiance for a red tide bloom off southern California. Aquat Microb Ecol 21: 31-47

> L'Helguen S, Slawyk G, Corre PL (2005) Seasonal patterns of urea regeneration by size-fractionated microheterotrophs in well-mixed temperature coastal waters. J Plankton Res 27:263-270

Laptikhovsky VV, Arkhipkin AI, Golub AA (1993) Larval stage, growth and mortality in the oceanic squid Sthenteuthis pteropus (Cephalopoda, Ommastrephidae) from 
the eastern tropical Atlantic. J Plankton Res 15:375-384

Lomas MW, Trice TM, Glibert PM, Bronk DA, McCarthy JJ (2002) Temporal and spatial dynamics of urea uptake and regeneration rates and concentrations in Chesapeake Bay. Estuaries 25:469-482

Longhurst A (1998) Ecological geography of the sea. Academic Press, San Diego, CA

Maranon E, Behrenfeld MJ, Gonzalez N, Mourino B, Zubkov MV (2003) High variability of primary production in oligotrophic waters of the Atlantic Ocean: uncoupling from phytoplankton biomass and size structure. Mar Ecol Prog Ser 257:1-11

McCarthy JJ (1972) The uptake of urea by natural populations of marine phytoplankton. Limnol Oceanogr 17: $738-748$

McCarthy JJ, Kamykowski D (1972) Urea and other nitrogenous nutrients in La Jolla Bay during February, March and April 1970. Fish Bull (Wash DC) 70:1261-1274

Metzler PM, Glibert PM, Gaeta SA, Ludlam JM (1997) New and regenerated production in the South Atlantic off Brazil. Deep-Sea Res I 44:363-384

Mulvenna PF, Savidge G (1992) A modified manual method for the detemination of urea in seawater using diacetylmonoxime reagent. Estuar Coast Shelf Sci 34:429-438

Partensky F, Hess WR, Vaulot D (1999) Prochlorococcus, a marine photosynthetic prokaryote of global significance. Microbiol Mol Biol Rev 63:106-127

Perez V, Fernandez E, Maranon E, Anxelu X, Moran G, Zubkov MV (2006) Vertical distribution of phytoplankton biomass, production and growth in the Atlantic subtropical gyres. Deep-Sea Res I 53:1616-1634

Poulton AJ, Holligan PM, Hickman A, Kim YN and others (2006) Phytoplankton carbon fixation, chlorophyll biomass and diagnostic pigments in the Atlantic Ocean. Deep-Sea Res II 53:1593-1610

Price NM, Harrison PJ (1987) Comparison of methods for the analysis of dissolved urea in seawater. Mar Biol 94: 307-317

> Price NM, Harrison PJ (1988) Urea uptake by Sargasso Sea phytoplankton: saturated and in situ uptake rates. DeepSea Res 35:1579-1593

Price NM, Cochlan WP, Harrison PJ (1985) Time course of uptake of inorganic and organic nitrogen by phytoplankton in the Strait of Georgia: comparison of frontal and stratified communities. Mar Ecol Prog Ser 27:39-53

$>$ Rees AP, Woodward EMS, Joint I (2006) Concentrations and uptake of nitrate and ammonium in the Atlantic Ocean between $60^{\circ} \mathrm{N}$ and $50^{\circ} \mathrm{S}$. Deep-Sea Res II 53:1649-1665

Remsen CC (1971) The distribution of urea in coastal and oceanic waters. Limnol Oceanogr 16:732-740

Robinson C, Poulton AJ, Holligan PM, Baker AR and others (2006) The Atlantic Meridional Transect (AMT) Programme: A contextual view 1995-2005. Deep-Sea Res II 53:1485-1515

Rocap G, Larimer FW, Lamerdin J, Malfatti S and others (2003) Genome divergence in two Prochlorococcus ecotypes reflects oceanic niche differentiation. Nature 424: 1042-1047

Roussenov V, Williams RG, Mahaffey C, Wolff GA (2006) Does the transport of dissolved organic nutrients affect

Editorial responsibility: Graham Savidge,

Portaferry, UK export production in the Atlantic Ocean? Global Biogeochem Cycles 20:GB3002. doi:10.1029/2005GB002510

San Martin E, Harris RP, Irigoien X (2006) Latitudinal variation in plankton size spectra in the Atlantic Ocean. DeepSea Res II 53:1560-1572

Sanders R, Jickells T (2000) Total organic nutrients in Drake Passage. Deep-Sea Res I 47:997-1014

Sanders R, Brown L, Henson S, Lucas M (2005) New production in the Irminger Basin during 2002. J Mar Syst 55: 291-310

Slawyk G, Raimbault P, L'Helguen S (1990) Recovery of urea nitrogen from seawater for measurements of ${ }^{15} \mathrm{~N}$ abundance in urea regeneration studies using the isotope-dilution approach. Mar Chem 30:343-362

Tamminen T, Irmisch A (1996) Urea uptake kinetics of a midsummer planktonic community on the SW coast of Finland. Mar Ecol Prog Ser 130:201-211

> Tarran GA, Heywood JL, Zubkov MV (2006) Latitudinal changes in the standing stocks of nano- and picoeukaryotic phytoplankton in the Atlantic Ocean. Deep-Sea Res II 53:1516-1529

Thomalla SJ, Turnewitsch R, Lucas M, Poulton A (2006) Particulate organic carbon export from the North and South Atlantic gyres: The ${ }^{234} \mathrm{Th} /{ }^{238} \mathrm{U}$ disequilibrum approach. Deep-Sea Res II 53:1629-1648

Varela MM, Bode A, Fernandez E, Gonzalez N, Kitidis V, Varela M, Woodward EMS (2005) Nitrogen uptake and dissolved organic nitrogen release in planktonic communities characterised by phytoplankton size-structure in the Central Atlantic Ocean. Deep-Sea Res I 52:1637-1661

- Varela MM, Bode A, Anxelu X, Moran G, Valencia J (2006) Dissolved organic nitrogen release and bacterial activity in the upper layers of the Atlantic Ocean. Microb Ecol 51:487-500

Vidal M, Duarte CM, Agusti S (1999) Dissolved organic nitrogen and phosphorus pools and fluxes in the central Atlantic Ocean. Limnol Oceanogr 44:106-115

Wafar MVM, Lecorre P, L'Helguen S (1995) $f$-ratios calculated with and without urea uptake in nitrogen uptake by phytoplankton. Deep-Sea Res I 42: 1669-1674.

- Watts LJ, Owens NJP (1999) Nitrogen assimilation and the $f$ ratio in the northwestern Indian Ocean during an intermonsoon period. Deep-Sea Res II 46:725-743

Wheeler PA, Kirchman DL (1986) Utilization of inorganic nitrogen by bacteria in marine systems. Limnol Oceanogr 31:998-1009

Wiltshire KH, Lampert W (1999) Urea excretion by Daphnia: a colony inducing factor in Scenedesmus? Limnol Oceanogr 44:1894-1903

> Young E (2007) A drop in the ocean. New Scientist 195(2621): 42-45

> Zubkov MV, Sleigh MA, Burkill PH, Leakey RJG (2000) Picoplankton community structure on the Atlantic Meridional Transect: a comparison between seasons. Prog Oceanogr 45:369-386

Zubkov MV, Fuchs BM, Tarran GA, Burkhill PH, Amann R (2003) High rate of uptake of organic nitrogen compounds by Prochlorococcus cyanobacteria as a key to their dominance in oligotrophic oceanic waters. Appl Environ Microbiol 69:1299-1304

Submitted: December 19, 2007; Accepted: May 27, 2008

Proofs received from author(s): September 17, 2008 